\title{
MEDETNIČNA DELITEV IN INTERAKCIJE NA GOSTIVARSKIH ULICAH'
}

Ključne besede: prostor, identitete, medetnični odnosi, kaos in kozmos

$\mathrm{V}$ pričujočem članku me zanima medetnična delitev in interakcije na ulicah mesta Gostivar. ${ }^{2}$ Čeprav v Gostivarju živijo različne etnične skupine, sem se osredotočila zgolj na albansko-makedonske odnose. Poudarila bi lahko predvsem dve izkušnji: zdi se, da so dekleta na ulicah izpostavljena verbalnemu nadlegovanju in nadzoru, fantje pa občasnim pretepom. Zanimalo me je, kako mladi dojemajo ulice ter kako etnična delitev v mestu vpliva na njihove percepcije prostora. Skozi raziskavo so se ulice pokazale kot eden izmed prostorov, kjer se oblikujejo identitete - tako spolne kot tudi etnične.

\section{Gostivar}

Gostivar je mesto v severozahodni Makedoniji (BJRM). Kot naselbino ga v pisanih virih prvič zasledimo v zapiskih rimskega zgodovinarja Livija

1 Članek izhaja iz diplomskega dela Kaos in kozmos med albanskim in makedonskim prebivalstvom $v$ Gostivarju, $v$ Makedoniji, Univerza v Ljubljani, Filozofska fakulteta, Oddelek za etnologijo in kulturno antropologijo, Ljubljana 2007. Diplomsko delo je nastalo pod mentorstvom red. prof. dr. Rajka Muršiča. Zanj sem prejela fakultetno Prešernovo nagrado.

2 Leta 2006/2007 sem devet mesecev preživela v Makedoniji, od tega pet mesecev v Gostivarju. Opravila sem številne nestrukturirane intervjuje $\mathrm{z}$ albanskimi in makedonskimi prebivalci mlajše generacije (letnik 1979 do 1988). Imena sogovornic in sogovornikov so spremenjena. 
pod imenom Drau-Dak ${ }^{3}$ (maj 2007). Leta 1394 je mesto prišlo pod turško oblast, leta 1883 pa so mu turške oblasti dodelile vlogo administrativnega središča. Po koncu druge balkanske vojne je to območje pripadlo Kraljevini Srbiji. Leta 1914 je Gostivar postal središče Gornopološkega območja, kar je še dandanes (Bilbiloski, 2000, 5-9; Konstantinov, 1992, 173).

Glede na popis iz leta 2002 ima mesto 35.847 prebivalcev, od tega 11.855 Makedoncev, 16.890 Albancev, 4.559 Turkov in 1.899 Romov. Celotna občina šteje 81.042 prebivalcev. Albanci predstavljajo 66,6 \%, Makedonci 19,5 \%, Turki 9,8 \%, Romi 3,8 \% ter drugi (Srbi, Bošnjaki, Vlahi) 0,3 \% (maj 2007).

Za boljše razumevanje medetničnih odnosov je potreben kratek vpogled v bližnjo preteklost. Po drugi svetovni vojni sta modernizacija in hitro rastoča industrija pospešili migracijo v mesta, ki je sprva zaobjela predvsem makedonsko prebivalstvo. Zaposlitveni vzorci so v Jugoslaviji, posebno pri administrativnih delih, imeli jasen etnični pečat. Brunnbauer ima to za posledico poskusa ustanovitve makedonskega naroda, zaradi česar so imeli koristi od države v glavnem etnični Makedonci. S tem se je spodbujal občutek pripadnosti »zamišljeni skupnosti« (Brunnbauer, 2002, 12; tudi Željazkova, 2003, 108; Korsika, 1989, 76-77). Poleg tega so imeli Albanci in Turki nižjo stopnjo izobrazbe ter so bili nižje kvalificirani kot pravoslavno slovansko prebivalstvo (Hodža, 1984, 57). Medtem ko so se Makedonci zaposlovali $\mathrm{v}$ rastočih državnih podjetjih, so Albanci začeli emigrirati na zahod. Velika nataliteta, nedostopnost trga dela (Albanci so bili večinoma zaposleni v kmetijstvu) ter povpraševanje po poceni delovni sili na zahodu naj bi pripomogli k izseljevanju v tujino (Publikacija 1, 2006, 33). Po razpadu Jugoslavije so cvetoča državna podjetja propadla. Število uradno registriranih služb se je od začetka devetdesetih let skoraj prepolovilo. Veliko število Makedoncev je ostalo brez kakršne koli državne podpore. Zaradi izgube virov prihodka (dostopa na jugoslovanski trg in uvedbe viz) ter nizke izobrazbe so ekonomsko in socialno krizo utrpeli tudi Albanci (de Rapper, 1998). Vendar se ti nikdar niso pretirano zanašali na državo. Bolj kot v državnem sektorju so bili zaposleni v malih zasebnih enotah, $s$ tem pa so imeli tudi prednost

3 (http://en.wikipedia.org/wiki/Gostivar <maj 2007>.

4 www.stat.gov.mk $<$ maj 2007> . 
v prihajajoči novi kulturi poslovanja (Poulton, 2000, 193). Rozita Dimova medetnične odnose razlaga skozi neoliberalni kontekst. Etnične identitete so bile od leta 1991 ponovno definirane skozi razred. Številni Makedonci, ki so bili v Jugoslaviji razmeroma privilegiran družbeni razred, stežka sprejemajo neposredno bližino, ki so jo Albanci po letu 1991 dosegli v fizičnem in družbenem prostoru. Preobrat v razredni mobilnosti, privilegijih in ekonomiji med albanskimi in makedonskimi prebivalci je pripomogel $\mathrm{k}$ medsebojnemu družbenemu oddaljevanju. Makedonci za izgubo svojih ekonomskih privilegijev in prejšnjega udobnega življenja krivijo Albance. Ta izguba je najbolj vidna skozi materialne dobrine, ki jih sedaj posedujejo Albanci (Dimova, 2005, 8-9). Če govorimo o medetničnem konfliktu, gre torej tudi za konflikt zaradi ekonomskih virov, ki so tesno povezani s politično močjo in organizacijo države (Brunnbauer, 2002, 14).

Prvi vtis v Gostivarju nam, z izjemo napisov v albanskem in makedonskem jeziku, ne da slutiti, da bi bilo mesto kakor koli razdeljeno glede na etnično pripadnost prebivalcev. A po pogovoru z ljudmi lahko hitro ugotovimo, da so ulice v mestu ločene na albanske in makedonske, pa tudi turške in romske. Če si ogledamo zemljevid mesta (slika 1), naj bi bilo središče albansko, oba obrobna dela pa makedonska. Tako je večina albanskih $k a-$ fičev $v^{5}$ na albanskih ulicah, makedonski kafiči pa so na makedonskih ulicah. Naj omenim, da je bil »mentalni zemljevid « narisan predvsem glede na mnenje makedonskih sogovornikov, ki ponavadi niso zaznavali razlike med Albanci in Turki. ${ }^{6}$ Ulica, na kateri sem živela, naj bi tako veljala za albansko, turški prijatelj pa mi je dejal, da je turška. Večina trgovin in lokalov je bila namreč turških (v stanovanjski hiši, kjer sem bivala, pa so stanovale makedonske družine). Tako je povsem mogoče, da so nekatere »albanske« ulice pravzaprav »turške« (vsaj v očeh turških prebivalcev).

5 Pri uporabi pogovornega izraza kafič imam v mislih lokale v Gostivarju, v katerih se zbirajo predvsem mlajši Gostivarčani in Gostivarčanke. V makedonskem jeziku uporabljajo izraz kafič v slengu, sicer pa uporabljajo tudi izraza kafanče in kafule; kafeana pa je manjša restavracija, kjer poleg pijače strežejo tudi hrano.

6 Albanci menijo, da so Turki le »poturčeni« Albanci. 


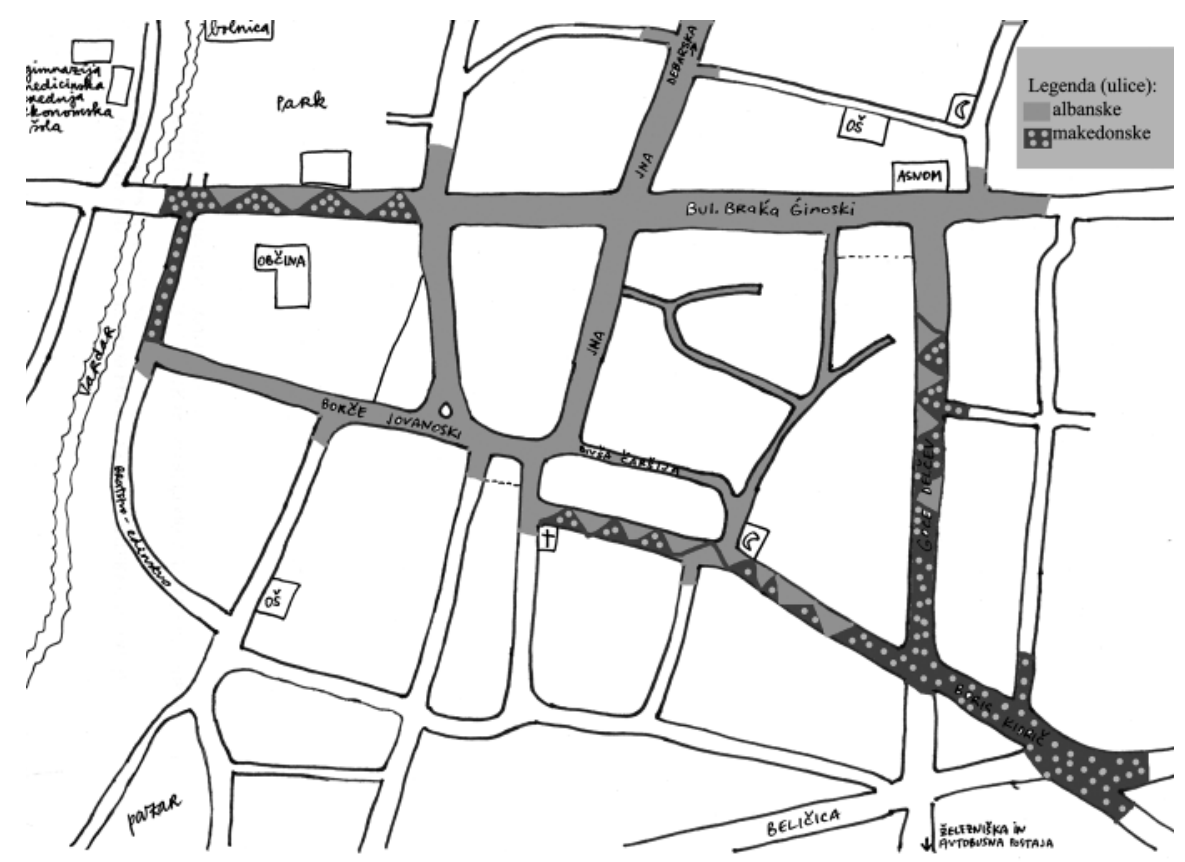

slika 1: Zemljevid gostivarskih ulic

Makedonski sogovornik pravi, da »za Makedonce dolgo ni bilo priporočljivo, da se sprehajajo po središču, toda nimaš izbire, tudi če se mu ogně̌, srečaš veliko Albancev«. Vsaj v mestnem središču je za Makedonce nujno, da se na poti v šolo, službo itd. vsakodnevno sprehajajo po albanskih ulicah. Na obisku pri makedonskih prijateljih je pogovor tekel o tem, kako so se njihovi starši sprehajali po korzu ter posedali na glavnem trgu. Nato so $\mathrm{v}$ šali dodali, da se danes »Šiptarji sprehajajo po korzu ter da zanje na trgu ni več prostora ${ }^{\prime}$. V petdesetih letih 20 . stoletja so porušili čaršijo; ${ }^{7}$ danes mesto tudi nima korza. To seveda ne pomeni, da se ljudje ne sprehajajo - sprehajanje je le bolj razpršeno ter ni omejeno na določeno ulico. Ob sprehajanju imam v mislih predvsem večerno sprehajanje v skupini prijateljev, ki je bolj intenzivno v poletnih mesecih, ko je na ulicah večja gneča, saj so v mestu tudi tisti, ki sicer živijo in delajo v tujini. Albanci naj bi se sprehajali po ulicah JNA, Debarski, Braḱe Gjinoski ter okoli glavnega trga, Makedonci pa

7 Mestna trgovska četrt. 
okoli makedonskega središča na ulici Boris Kidrič. Ena izmed sogovornic, Mariana, pravi: »In sedaj, č je petek ali sobota, če te nekdo vidi na tem delu [Ulica JNA - op. p.], se mu bo zdelo čudno. /.../ Vprašal se bo, kaj iščeš tukaj, ker to ni naš del; tam je naš del.»

Dojemanje prostora je torej med prebivalkami in prebivalci Gostivarja vezano na etnično pripadnost. Če se v določenih situacijah zavestno odločajo ter izogibajo prostorom »drugih «, pa to ni vedno mogoče. Da lahko razumemo dinamiko mestnega javnega življenja ter interakcije med prebivalci, potrebujemo nekaj temeljnih konceptov, med katerimi je na prvem mestu prostor oziroma koncept prostora. »Čeprav predstava prostora ( $s p a$ ce) neposredno ne nakazuje družbene strukture in družbenih odnosov, je del družbenega sistema ter v vsaki družbi določa predstavo »sebstva«« (Brumen, 1998, 71). Muršič namesto o prostoru razmišlja o prostorjenju (spatialization): "Namesto predmetov, ki jih ustvarjamo ali preoblikujemo, moramo v ospredje postaviti dejavnost in dejanja, prakse, izkustvo (telesenja, prostorjenja) in tvornost.« $(2006,53)$ Ob razmišljanju o prostoru moramo dati prednost procesu njegove družbene konstrukcije, dejavnemu prostorjenju in ne samemu prostoru in njegovim konkretizacijam, kot so (po)krajina, območje, kraj, mesto, nahajališče ali lokacija (Muršič, 2006, 51).

Kot piše Ardener, »družbe svoja kulturno pogojena pravila proizvajajo tako, da postavijo ločnice na terenu; $\mathrm{z}$ nevidnimi ograjami in prepadi družbeno razdelijo v sfere, nivoje in teritorije.« $(1997,2)$ Če predpostavljamo, da sta obnašanje in prostor medsebojno odvisna, nam okolje »nalaga določene omejitve pri gibanju, naše predstave o prostoru pa se oblikujejo $\mathrm{z}$ našo zmožnostjo gibanja« (Ardener, 1997, 2). Prav tako kot prostor definira ljudi v njem, tudi ljudje definiramo prostor (Ardener, 1997, 3). Univerzalna praksa je, da v duhu določimo domači (naš) prostor in tuji prostor (onkraj našega). Dovolj je, da določimo meje v svoji glavi. Ozemlje in mentaliteta njih sta s tem označena kot drugačna od naših. Predmetom, prostorom in časom tako pripisujemo vlogo in nadevamo pomene, ki pridobijo vrednost objektivne realnosti šele potem, ko smo jim vse to že pripisali (Said, 1996, 74-75).

Dojemanje prostora in ločnic med varnim in nevarnim želim navezati na koncept kaosa in kozmosa po Mirceaju Eliadeju. Če kozmos obravnavamo kot pojem logike, ki diktira red, razliko in opozicijo, kaos pomeni 
nevarnost. Njun odnos določamo tako, da sebe postavimo v kozmos. Kot pravi Eliade, je »središče predvsem prostor svetega, prostor absolutne resničnosti« $(1992,29)$. Če se oddaljimo od središča, izginjata domačnost in varnost znanega, hkrati pa se povečuje nevarnost. Z binarnimi opozicijami svoje : tuje, urejeno : neurejeno, varno : nevarno, blizu : daleč, znano : neznano si pomagamo zadovoljiti potrebo po varnem prostoru okoli sebe (Risteski, 2000). Posameznik v neznanem in nedomačem ne zna določiti reda. Ko se znajdemo v neznanih situacijah, v že znanem in doživetem iščemo tisto, $s$ čimer bi lahko novo situacijo doumeli ter se torej znali obnašati v njej (Cohen, 1994, 139-141; Douglas, 2004, 46). Ardener navaja, da »skupnosti prostor najbližji družini pogosto dojemajo kot varen in predvidljiv notranji svet, $\mathrm{v}$ nasprotju s potencialno nevarnim in nezanesljivim svetom zunaj. Ločnica, ki deli ta dva svetova, pa se razlikuje tako med kulturami kot znotraj različnih kontekstov iste kulture.« $(1997,10)$

Določanje središča pomeni označevanje prostora, ki s tem pridobiva pomene, funkcije in simboliko. Njegovo ohranjanje je skoraj tako pomembno kot ohranjanje in obnavljanje ločnic (Risteski 2000). Zdi se torej, da kaos narašča $\mathrm{z}$ oddaljevanjem od središča (doma, domačnosti). Za Makedonce doseže vrhunec v »čistih « albanskih vaseh (prostorska in etnična oddaljenost), kjer se mladi Makedonci ne počutijo varno, temveč negotovo, neprijetno oziroma preplašeno. Vsesplošno mnenje je, da Makedonci ne morejo vstopiti v albanske vasi. Kot je dejal Igor, bi ga »v najboljšem primeru pretepli«. Lahko bi dejala, da Makedonci navajajo več mest, kjer se ne počutijo varne, medtem ko za Albance takšna mesta skorajda ne obstajajo. Hkrati je med makedonskimi prebivalci zaznati več strahu pred albanskimi predeli kot obratno.

$\mathrm{V}$ nadaljevanju se bom podrobneje posvetila analizi interakcij na gostivarskih ulicah ter osvetlila različne percepcije in dojemanja s strani makedonskih ter albanskih fantov in deklet.

\section{Ulice}

Makedonska dekleta nerada sama hodijo po mestu, posebno ob večerih.

Večina jih meni, da mesto ni varno zaradi Albancev oziroma albanskih fantov. Albanski fantje naj bi dekleta ogovarjali z vulgarnimi izrazi: »Vse 
živo govorijo, da te je strah, ko greš mimo njih; nekdo bo stopil pred tebe, te ogovarjal, in to ne samo eden, več jih je, in če si sama ali sta dve, se desetim moškim okoli sebe ne moreš postaviti po robu, za žensko je zagotovo veliko bolj strašno /.../ Zato prakticiram, da imam kakšnega fanta ob sebi, ker so se mi že dogajale takšne stvari in ne želim, da se mi ponovijo."

Tudi makedonski fantje opažajo, da so dekleta podvržena nadlegovanju: »V šoli je celo meni neprijetno, /.../ ker sedijo na obeh straneh na mizah ali klopeh, in ko greš mimo, vedno gledajo dekleta in komentirajo, delajo probleme /.../ Razumem, da pogledaš, toda to je že napadalno. "Kot pravi Vlado, ga takšno obnašanje albanskih fantov moti. Nasprotno albanski sogovornik Bekim pri tem ne vidi etnične razlike: »Lahko se zgodi tudi, da ima Makedonka težave s kakšnim Makedoncem, ki popiva dolgo v noč巛. Vendar tudi on poudarja, da za dekleta zvečer ni varno, da bi se sprehajala sama: »Obstajajo različni ljudje, tu še ne deluje pravna država, sistem ne deluje, kot bi moral. "Izpostavil je problem korupcije: "Kako naj te policija varuje in brani, ko ve, da ima lahko jutri težave zaradi tega."

Albanskim dekletom se zdi manj problematično, da bi šle same po mestu. Počutijo se bolj varne, vendar imajo tudi one raje, če gredo z družbo. Lume zvečer redko hodi sama, navadno gre z bratom ali družbo. Pravi, da je tako navajena od otroštva: »Ne da bi bilo problematično, toda naučila sem se, da grem $z$ družbo in zato se ne morem navaditi, da bi šla sama; neudobno mi je, sami pri sebi mi je neudobno, saj mi nihče ne brani, da ne bi šla sama."

Tudi Vale de Almeida v portugalskem mestu opaža, da se dekleta od malega naučijo po ulicah sprehajati se v parih $(1996,50)$. »Različnih spolnih vlog se naučimo v otroštvu. Krepijo jih številne neformalne sankcije. Mladim dekletom dodeljujejo gospodinjska opravila, zaradi katerih so bolj vezana na dom kot njihovi bratje. $Z$ odraščanjem jim dodeljujejo strožje "policijske ure«, njihov videz in vedenje pa sta pod budnim očesom javnosti. Ostale naj bi urejene in skromne, izogibale naj bi se pretirani spontanosti in odkritosti, saj se lahko takšno obnašanje prenaša na področje seksualnosti. Od fantov se pričakuje, da živijo bolj svobodno, da ostanejo zunaj, kolikor dolgo želijo, pijejo s prijatelji ter iščejo žensko družbo." (Brandes, 1981, 218; tudi Vale de Almeida, 1996, 49-50). Če so dekleta torej vpisana v 
družbeno okolje z opozicijo med javnim (moškim) in privatnim (ženskim) prostorom, ulica predstavlja prostor nevarnosti (Bourdieu, 1998, 64).

Vendar bi bila predpostavka, da imajo moški zaradi svojega položaja $\mathrm{v}$ javni sferi večji prestiž ali avtoriteto, prehitro sklepanje. Po Boškoviću naj bi odnose med moškim in žensko bolje razumeli skozi koncept komplementarnosti, kjer moški in ženska prav zato, ker sta različna, zagotavljata različne (in recipročno združljive) elemente, ki omogočajo delovanje skupnosti (2000, 16). Svetieva razlikuje med idealnim modelom tradicionalne kulture, kjer je prevladoval moški princip, ženska pa je bila podvržena ubogljivosti in podrejanju, ter resničnim modelom, kjer je ženska pridobila pomembne latentne pravice ter sodelovala pri oblikovanju ljudske kulture (Svetieva, 2000). Podobno Schubertova za Makedonijo piše, da se »v javni sferi ženska ne zapleta $\mathrm{v}$ neposreden konflikt moči ali avtoritete $\mathrm{z}$ moškim, s katerim ni v sorodu, vendar pa takšne odnose upravlja skozi druge ženske« (Schubert, 2005).

\section{Kulturne razlike}

Zdi se, da se mladi na ulicah srečujejo s podobnimi situacijami, vendar pa jih različno dojemajo in interpretirajo. Vzroke za razhajanja skušam interpretirati skozi različne poglede, na prvem mestu skozi kulturne razlike med albansko in makedonsko mladino.

Tako kot makedonska tudi albanska dekleta poznajo ogovarjanje na ulici. Lume pravi, da če je sama, jo fantje ogovarjajo: »Bog ne daj, da bi bila preveč zrihtana, takrat je že konec, pa tudi če nisi zrihtana, te bodo ogovarjali ali ti sledili.«

Pa vendar bi lahko na podlagi opažanj dejala, da albanska dekleta ogovarjanju na ulici ne pripisujejo tolikšne teže kot makedonska. Kot pravi Ardita: "Gre za to, koliko jih boš ignorirala; pogledala bi ga in molčala, se ne odzvala, morda bi nadaljeval in še kaj rekel ali zažvižgal, nikoli pa se mi ne bi približal in se me dotaknil, ker ve, da bi takoj nekdo prišel, morda sosed, nekdo bi prišel in se spravil nadenj; vsi vedo, da se ti tukaj nihče ne more približati in te napasti.. 
V svoji raziskavi o južnoafriški skupnosti Ridd piše, da »ženske ulično življenje povezujejo $\mathrm{z}$ neredom (ulica je moško območje), kar je v nasprotju z njihovimi težnjami po ugledu. Vendar pa, če se ženska ponoči odpravi na ulico, to stori z mero gotovosti, ki ji jo dajeta status ženske, matere in gospodinje ter spoštovanje, ki presega izkazovanje kavalirstva.« $(1997,194)$

Tako makedonska kot albanska dekleta se na ogovarjanje odzivajo $\mathrm{z}$ ignoriranjem, vendar pa je pri makedonskih dekletih mogoče zaslediti močne občutke strahu in ogroženosti. Zdi se, da Albanke posedujejo zavedanje, ki ga Makedonke nimajo. Gre za zavedanje o meji med verbalnim ogovarjanjem in dejanji, ki je fantje ne bi presegli. To zavedanje daje albanskim dekletom občutek varnosti, njegovo pomanjkanje pa pripomore $\mathrm{k}$ strahu med makedonskimi dekleti.

Zdi se, da makedonski fantje $\mathrm{k}$ dekletom ne pristopajo na enak način kot albanski. V svoji raziskavi o rapu med Afroameričani Kochman opaža, da »moški in ženske določeno obnašanje razlagajo v skladu s pomenom in vrednostjo, ki ju ima znotraj njihove lastne kulture $(1997,97)$. Nesporazumi torej nastanejo, kadar se način komunikacije med različnimi skupinami razlikuje. Kochman si rap med Afroameričani razlaga kot običajen in sprejemljiv način odprtega in neposrednega pogajanja med moškim in žensko, ki pa ga belci ne poznajo in zanje ni sprejemljiv. Tako se Afroameričanom njihov pristop ne zdi nespodoben, se pa zdi takšen belcem. Podobno je ogovarjanje albanskih fantov za Makedonce nespodobno, verjetno pa je (do neke mere) povsem sprejemljivo med Albanci (po Kochman, 1997, 98). Morda je tako kot v Andaluziji med Albanci »uspeh pri ženski močna potrditev samopodobe« ter je "glavno zagotovilo uspeha pri ženskah, če veš, kako govoriti z njimi« (Pitt Rivers, 1972, 92 in 94).

\section{Sorodstvo}

Naslednjo možno interpretacijo različnih dojemanj interakcij na ulicah bi lahko usmerili v sorodstvene vezi. Ardita pravi, da se ji kot ženski ne more nič zgoditi, ker je mesto majhno in se vsi poznajo. Ko sem ji povedala, da se Makedonke bojijo same sprehajati ob večerih, je bila presenečena. 
Dejstvo, da se albanska dekleta počutijo varnejše, bi lahko pripisali temu, da so v mestu Albanci v večini in se večinoma vsi poznajo: »Ljudje se bojijo delati takšne stvari /.../ Gre bolj za spoštovanje, saj vedo, da si lahko sestrična nekoga, ki ga poznajo."

"Albanska družba v Makedoniji in na Kosovu je močno osrediščena okoli razširjenih družin, sorodstvene vezi so močne.« (Poulton, 2000, 194) Brunnbauer dodaja, da imajo med Albanci »družina in sorodstvene vezi mnogo večji pomen zaradi pomanjkanja zaupanja v formalne institucije» $(2002,15)$. Tako pri Makedoncih kot pri Albancih med bližnje sorodnike uvrščajo tudi bratrance in sestrične iz drugega in tretjega kolena. Pojem bližnjih sorodnikov se včasih razširi do petega kolena (Bošković, 2000, 6). Glede na to, da so poroke med Albanci in Makedonci izjemno redke, se tudi sorodstvene vezi ne prepletajo. Sorodstvo je torej lahko eden izmed vzrokov, da so albanski fantje do Makedonk bolj drzni, saj vedo, da niso sorodstveno povezani in za seboj nimajo (albanskih) sorodnikov, ki bi jih branili. Če torej Albankam ulice v tem smislu pomenijo sistem pozitivnega družbenega nadzora, ki ženski daje občutek varnosti, to za Makedonke ne velja.

\section{Družbeni nadzor}

Kot že rečeno, je prav družbeni nadzor tisti, ki pogosto narekuje določene vzorce obnašanja. Ob neki priložnosti sem se z Mariano dogovorila, da se dobiva pri meni. Nato pa mi je poslala sporočilo, če lahko pridem na avtobusno postajo, nakar sva skupaj odšli do pet minut oddaljenega stanovanja. Šele kasneje sem pomislila, da je stanovanje v »albanski« ulici ter bi bilo »čudno«, če bi se Mariana sama sprehajala po njej. Zdi se, da obnašanje (predvsem) deklet na ulicah pogojujejo mehanizmi družbenega nadzora. Izpostavljanje oziroma zoperstavljanje družbenim normam se lahko konča v opravljanju ter obrekovanju. Strah pred izgubo dobrega imena in časti dekleta sili, da se izogibajo situacijam, ki bi lahko vodile v opravljanje.

"Človekovo obnašanje določajo formalni in neformalni mehanizmi družbenega nadzora. Družba vpliva na svoje člane in jih nadzoruje tako, da sprejemajo njena pravila in norme. To vključuje pripravljenost delovati 
v skladu s pričakovanji.« (Ramšak, 2006, 197) »Čast ženske je odvisna od ugleda, ki ji ga je pripravljena podeliti skupnost, in ne od težko določljivih dokazanih dejstev. Ženska svojo čast najbolj učinkovito zavaruje, če svoje obnašanje v vsakem pogledu prilagaja kodu spolnega sramu.« (Campbell, 1974, 270)

Če bi makedonsko dekle samo videli na albanski ulici, bi se na primer lahko razširila vest, da ima albanskega fanta. Glede na to, da je ulica prostor, kjer smo vsem na očeh, ter da se tudi albanska dekleta pogosto sprehajajo $\mathrm{v}$ spremstvu, se zdi, da se dekleta s spremstvom zavarujejo pred situacijami, ki bi vodile v opravljanje. Kot pravi Ardita, »obstaja velika razlika med fantom in dekletom - težko je biti dekle, vedno moraš paziti, kako se obnašaš in kaj rečeš, kam greš in s kom govoriš«. Kot pravi Bourdieu, je logika moške dominacije in ženskega podrejanja tako vtisnjena $\mathrm{v}$ družbene subjekte, da so ženske ženskam (z opravljanjem) pravzaprav največje sovražnice (1998, 43 in 46).

Opravljanje in ogovarjanje sta možni obliki družbenega nadzorovanja in vzpostavljanja reda. Kot pravi Campbell, je opravljanje oblika »zunanjih sankcij, ki podpirajo notranje sankcije posameznikovih dejanj, samospoštovanje in občutek sramu« $(1974,315)$. Prek opravljanja se seznanjamo s tem, kaj je prav in kaj narobe. Hkrati se oblikujejo vrednote in morala skupine, opravljanje pa skupnost tudi povezuje. Ob opravljanju drugega poudarjamo lastno poštenost in prestiž (Campbell, 1974, 314).

\section{Način oblačenja}

Poulton predpostavlja, da se nemuslimanke počutijo kot objekt neodobravanja s strani albanskih moških. Ogrožene se počutijo zaradi načina oblačenja $(2000,194)$. Željazkova pa piše, da se Albanke v Skopju oblačijo bolj konservativno kot v Gostivarju in Tetovu $(2003,94)$.

V Gostivarju se je marsikateri znanec pritoževal, da se mlade Albanke oblačijo pretirano pomanjkljivo celo za $\mathrm{v}$ šolo ter da po ličilih prekašajo makedonska dekleta. Glede pravil oblačenja Ardita meni, da je religija pri Albancih močno pomešana s tradicijo: »Če se skregam $z$ mamo zaradi ma- 
jice s kratkimi rokavi, najprej reče: ne pojdi ven, ker te bodo vsi videli napol golo. Ko ji rečem, da me drugi ne zanimajo, pa odgovori: ne pojdi ven, ker te bo Bog kaznoval." Med pravili oblačenja v islamu in emancipacijo Arditini starši iščejo kompromise: "Lahko oblečem vse razen majice brez rokavov, lahko pa imam majico s kratkimi rokavi; po islamu ne bi smela nositi nobene /.../ Gre za razliko treh centimetrov blaga. "Vendarle pa način oblačenja zagotovo vpliva na ogovarjanje na ulicah. Dekleta naj bi bila deležna ogovarjanja predvsem, kadar gredo zvečer ven. Takrat so navadno oblečena lepše in so bolj našminkana.

\section{Patriarhalni vzorci}

Na koncu bi lahko izkušnje deklet povezala s patriarhalnimi vzorci, ki se prav tako navezujejo na družbeni nadzor. Patriarhat lahko definiramo kot vrednostni sistem, vpet v družbeno strukturo, ki kot dejavnike oblikovanja poudarja spol in starost. Takšno strukturiranje je povezano z opredelitvijo sistema vrednot, ki vodi družinsko življenje in širše družbene enote (Halpern in Kaser, 1997, 1). Podrejanje ženske znotraj konteksta preveč zaščitniške družine in okolice naj bi se skladalo $\mathrm{z}$ omenjeno strukturo.

Kot je dejal makedonski sogovornik, ob večerih svoje prijateljice pospremi zaradi nadlegovanja in ogovarjanja, ki so ga deležne na ulicah. Čeprav se zdi, da so Albanke ogovarjanju podvržene v manjši meri ali pa mu ne pripisujejo tolikšne teže, tudi one ob večerih redko hodijo same. Brandes omenja spremstvo deklet v Andaluziji: »Razen ob nedeljskem korzu naj bi se ženske izogibale kroženju po ulicah. Kadar pa se že sprehajajo, naj bi imele spremstvo še ene ženske ali moškega sorodnika.« $(1981,217)$

Nekaj časa sem preživela tudi v Svetem Nikole, mestecu v vzhodni Makedoniji. Med prebivalci velja za varno in mirno mesto, in sicer zato, ker je »čisto « - se pravi, da tam živijo le Makedonci. Če Makedonci v Gostivarju menijo, da dekleta potrebujejo spremstvo, ker mesto ni varno, pa imajo dekleta spremstvo tudi v Svetem Nikole, ki velja za varno mesto, saj v njem ni Albancev. Poulton omenja, da »številni raziskovalci govorijo o tradicionalnem patriarhalnem sistemu pri Albancih ter njihovih prevladujočih 
muslimanskih navadah in običajih « $(2000,194)$. Toda ali gre res le za muslimanske navade? Po Loryju »ni mogoče razločevati med delovanjem tradicionalnih patriarhalnih kmečkih moralnih načel, vplivom pravoslavnega krščanstva in vlogo otomanske kulture (ter v tem primeru islama)« (po Todorova, 2001, 276). Bourdieu piše o absorbiranju, v katerega logiki je tudi kavalirska protekcija, ki lahko vodi v omejevanje ali služi njegovemu opravičevanju ter pripomore $\mathrm{k}$ temu, da ženske pri stikih s svetom drži v razdalji, saj zanj »niso narejene«, ker svet ni narejen zanje (1998, 68-69). Čeprav ne morem trditi, da je spremstvo v Gostivarju pravilo, pa je bolj ali manj navzoče tako med makedonskimi kot albanskimi dekleti, ki so pogosto (predvsem v večernih urah) vezana na spremstvo. S tem ko je ženski dodeljeno spremstvo, je podvržena nadzoru.

\section{Pretepi}

Doslej sem nekoliko več prostora namenila analizi izkušenj deklet. Kako pa ulice dojemajo fantje? Če so makedonska dekleta na ulicah izpostavljena ogovarjanju in nadlegovanju, naj bi bili fantje izpostavljeni pretepom. Igor je doživel kar nekaj konfliktov $\mathrm{z}$ albanskimi vrstniki: »Vse to zaradi njihovega provociranja /.../, najpogosteje sem se umaknil, ker jih je bilo preveč. Najpogosteje se držijo skupaj; tudi ko gredo po ulici, ne moreš videti dveh ali treh, temveč po deset skupaj [smeh - op. p.], preprosto se jim ne morě̌ postaviti po robu. Zgodilo se mi je, da me je na ulici Albanec porinil, porinil sem ga nazaj, bil sem $z$ dekletom, on pa se je vrnil še $z$ dvajsetimi prijatelji. Obkolili so me sredi centra, ljudje so hodili mimo, kot da ni nič, končalo pa se je z običajnimi modricami.«

Albanska sogovornika nasprotno pravita, da ne vesta za pretepe oziroma da se dogajajo redko, sploh pa ne v zadnjem času: »Morda so se dogajali $v$ srednji šoli, ampak mislim, da ni več takšnih bedarij. « Jeton pravi, da do danes v mestu ni videl pretepa. Bekim dodaja, da so se tepli na avtobusu na poti v srednjo šolo v Tetovo. Avtobusi so bili za makedonske in albanske učence ločeni: »Kadar smo se hoteli tepsti, smo šli na njihov avtobus [makedonski - op. p.] in delali probleme, oni pa v naš; ne, oni ne, le mi smo šli in 
delali probleme. «Vendar pa pravi, da so s fanti, s katerimi so se nekoč tepli, danes najboljši prijatelji. Do pretepov naj bi prihajalo tudi v diskotekah. Do njih lahko pride, če v diskoteki albanski fant pleše z Makedonko in v podobnih situacijah. Morda zaradi strahu pred pretepi mladi Makedonci ne bi šli v albanski kafič ali diskoteko oziroma bi šli s strahom in občutkom negotovosti. Vendar Vlado pravi, da do pretepov prihaja v vseh diskotekah, ne le albanskih, o katerih se največ govori, a kljub temu: »Vedno je obstajal ta strah, lahko naredijo probleme za prazen nič; mislim pa, da bi večini predstavljalo problem, ker sem jaz Makedonec. In zakaj bi sploh šel v albansko diskoteko, če imamo makedonsko."

V svojem diplomskem delu o življenju mladih v Velenju Irena Rudolf med drugim piše tudi o pretepih. Izpostavlja »manifestacijo (tradicionalne) moškosti in z njo povezane moči ter »slab « socialni položaj« $(2006,83)$. Gre za pravila ulice, pomembno je, da »nisi prpa oziroma strahopetec, da si drzen, se znaš postaviti zase ter si s tem pridobiš ugled in spoštovanje. Potrebno je torej stalno dokazovanje.« (Rudolf, 2006, 59) Kot opaža Rudolfova, je pomembno, »da imaš »enega za sabo«. /.../ »Prpa« namreč ne pomeni le strahopetca, ampak tudi tistega, ki nima zaledja in s tem grožnje svojemu napadalcu. Pravilo ulice namreč niti ni »mož na moža«, ampak kar cela skupina na posameznika.« $(2006,59)$

Če so ženske podrejene socializaciji, ki jih sili k odpovedovanju in jih postavlja v ozadje, pa moški niso nič manj ujetniki in žrtve svoje dominanthe reprezentacije (Bourdieu, 1998, 55). Moškost (virilité) deluje v odnosu $\mathrm{z}$ drugimi moškimi ter $\mathrm{v}$ strahu pred poženstvenostjo, žensko in samim seboj. Z izgubo samozavesti ali priznavanja skupine moški pristane v kategoriji žensk, kar je zanj največja žalitev. Moškost mora biti torej predvsem veljavna v očeh drugih moških, vsak moški mora v vseh pogledih svojo moškost nenehno dokazovati, $v$ resničnosti aktualnega ali potencialnega nasilja pa mu je zagotovljeno priznanje (Bourdieu, 1998, 56-59). Morda bi tako pretepe kot ogovarjanje na ulici lahko postavili v kontekst dokazovanja moškosti. 


\section{Sklep}

Lahko bi torej sklenila, da je ulica eden izmed prostorov, kjer se soočata kaos in kozmos, moški in ženski pogled, prav tako pa tudi pogledi različnih etničnih skupin. Skozi definiranje ločnic v prostoru se ustvarjajo in ohranjajo ločnice med »nami« in »njimi«, kar lahko povežemo z identificiranjem. Identitete se gradijo $\mathrm{v}$ procesu interakcije $\mathrm{z}$ različnimi drugimi ter so zgrajene skozi razlike. Le skozi odnos s tem, kar ni, s tistim, kar mu manjka, kar je bilo imenovano konstitutivna zunanjost, se lahko gradi pozitiven pomen katerega koli pomena - in torej njegove identitete (Derrida, Laclau in Butler, po Hall, 1996, 4 in 5).

Identificiranje je povezano tudi s prostorom, saj se ločnice med kaosom in kozmosom, med »nami« in »njimi« rišejo prav v njem. Kot pravi Barth, se etnična identiteta artikulira na ločnicah (boundaries), kjer se etnične skupine srečujejo. Identiteta vsake skupine je prilagojena identiteti druge skupine, ki jo hkrati tudi oblikuje (po Cohen, 1994, 10). Proces identificiranja poteka $\mathrm{z}$ določanjem podobnosti $\mathrm{z}$ »nami« ter razlik od »nas«, ki smo v središču. Drugega postavljamo v sfero kaosa, saj pomeni oddaljeno, tuje, neznano, neurejeno, nevarno in nečisto. Sebe postavimo v sfero kozmosa, ki jo enačimo z domačim, poznanim, urejenim, varnim ter čistim.

Tako kot »etničnost (kot eno od ultimativnih identitet skupaj z lokalnimi, regionalnimi, spolnimi, religioznimi, razrednimi in generacijskimi identitetami) vedno znova izumlja in interpretira vsaka generacija, celo vsak posameznik « (navajam Marcus in Fischer, po Muršič, 1997, 231), se hkrati izumlja in interpretira tudi prostor, $\mathrm{v}$ katerem se (etnične in spolne) identitete vzpostavljajo.

Lahko bi dejala, da je v dveh razmeroma zaprtih sobivajočih etničnih skupinah občutek časti in osebne identitete $\mathrm{v}$ precejšnji meri in včasih popolnoma odvisen od članstva $v$ teh skupnostih (po Blok, 1984, 61-62). Javno mnenje ima pomembno vlogo pri ohranjanju identitete in ločnic. Predvsem dekleta morajo paziti na svoje dobro ime oziroma čast, ki je pod stalnim nadzorom. Po Barthu naj bi etnične skupine temeljile na razlikah: »Nasprotje med »nami« in »drugimi« je vtisnjeno v organizacijo etničnosti: drugost drugih je izrecno povezana $\mathrm{z}$ obrambo kulturnih razlik.« (Barth, 1995) Zdi se torej, da se identificiranje vzpostavlja tudi z izogibanjem pro- 
stora »drugega «. Posamezniki se mu izogibajo, da bi ohranili dobro ime v očeh družbe. Skozi nenehno vzpostavljanje identitet ter ločnic med »nami« in »njimi« ali med kaosom in kozmosom se kaže tudi strah pred izgubo identitete. Vsaka stran se namreč boji, da bi postala to, »kar so oni«.

\section{LITERATURA}

Ardener, S., Ground rules and social maps for women: An introduction, v: Women and space: Ground rules and social maps (ur. Ardener, S.), Oxford, New York 1997, str. 1-30.

Barth, F., Ethnicity and the concept of culture, 1995 (dostopno na: http:// www.wcfia.harvard.edu/ponsacs/docs/s95barth.htm).

Bilbiloski, J., 96te gostivarski sela. Skopje 2000.

Blok, A., Rams and Billy-Goats: A key to the Mediterranian Code of Honour, v: Religion, Power and Protest in Local Communities: The Northern Shore of the Mediterranean (ur. Wolf E.), New York 1984, str. 51-70.

Bourdieu, P., La domination masculine. Seuil 1998.

Bošković, A., The Other Side of the Window: Gender and Difference in Prespa, Republic of Macedonia, Série Antropologia 269, 2000. (dostopno na: http://www.unb.br/ics/dan/Serie269empdf.pdf).

Brandes, S., Like wounded stags: Male sexual ideology in an Andalusian town, v: Sexual meanings: The cultural construction of gender and sexuality (ur. Ortner B. S. in Whitehead H.), New York 1981, str. 216-239.

Brumen, B., Time, space and social construction of identity, v: MESS, Mediterranean Ethnological Summer School, Vol. 2 (ur. Baskar B. in Brumen B.), Ljubljana 1998, str. 71-84.

Brunnbauer, U., The implementation of Ohrid agreement: ethnic Macedonian resentments, Journal on Ethnopolitcs and Minority Issues in Europe 1, 2002 (dostopno na: http://www.ecmi.de/jemie/download/Focus12002Brunnbauer.pdf). 
Campbell, J. K., Honour, family and patronage: A study of institutions and moral values in a Greek mountain community, Oxford in New York 1974.

Cohen, A., Self-consciousness: An alternative anthropology of identity, London in New York 1994.

De Rapper, G., Crisis in Kosovo: Reactions in Albania and Macedonia at the Local Level, Ethnobarometer Programme Working Paper 3, 1998 (dostopno na: http://www.ethnobarometer.org/pdf/wp03.pdf).

Dimova R., Consuming the "Other «: The South Eastern European Case, v: EthnoAnthropoZoom, Journal of the department of Ethnology, 2005 (dostopno na: http://www.iea.pmf.ukim.edu.mk/EAZ/EAZ_05/EAZ_ 2004_PDF/Dimova_Rozita_EAZ_2005_eng.pdf).

Douglas, M., Purity and danger: An analysis of the concepts of pollution and taboo, London in New York 2004.

Eliade, M., Kozmos in zgodovina: Mit o večnem vračanju, Ljubljana 1992.

Hall, S., Introduction: Who needs identity?, v: Questions of cultural identity (ur. Hall, S. in drugi), London 1996, str. 1-17.

Halpern, J. M. in Kaser K., Contemporary research on the Balkan family, anthropological and historical approaches, v: Bulletin of the Ethnographical Institute SASA, Vol. 46, Beograd 1997, str. 63-72 (dostopno na: http://www.rastko.org.yu/antropologija/glasnici-ei/46/kkaser_e.pdf).

Hodža, H., Afirmacija albanske nacionalnosti u Jugoslaviji, Priština 1984.

Kochman, T., Race, Culture and Misunderstanding, v: Conformity and conflict (ur. Spradley J. in MacCurdy D.), New York 1997, str. 89-102.

Konstantinov, M., Makedonci, Skopje 1992.

Korsika, B., Srbija i Albanci: Pregled politike Srbije prema Albancima od 1944. do 1989. godine, knjiga treća, Časopis za kritiko znanosti 128, Ljubljana 1989.

Muršič, R., »Razkritje krinke«: O lokalno-globalnih identifikacijah. Traditiones 26, 1997, str. 223-236.

Muršič, R., Nova paradigma antropologije prostora: Prostorjenje in človeška tvornost, Glasnik SED $46(3,4), 2006$, str. 48-55. 
Pitt - Rivers, J., The people of Sierra, Chicago, London 1972.

Poulton, H., Who are the Macedonians?, London 2000.

Publikacija 1, How to make economy of Gostivar a champion?, Skopje 2006.

Ramšak, M., Žrtvovanje resnice: Opoj zmuzljivih diskretnih nediskretnosti, Maribor 2006.

Ridd, R., Where women must dominate: response to opression in a South African urban community, v: Women and space: Ground rules and social maps (ur. Ardener, S.), Oxford, New York 1997, str. 183-199.

Risteski, L., Space and boundaries between the worlds, v: EthnoAnthropoZoom, Journal of the department of Ethnology, 2000 (dostopno na: http:// iunona.pmf.ukim.edu.mk/etnoantropozum/Risteski\%20Ljupcho-angl\%20.htm).

Rudolf, I., Velenje je geto: Zgodbe o življenju mladih v mestu. Neobjavljeno diplomsko delo, Univerza v Ljubljani, Filozofska fakulteta, Oddelek za etnologijo in kulturno antropologijo, Ljubljana 2006.

Said, E., Orientalizem: Zahodnjaški pogledi na Orient, Ljubljana 1996.

Schubert, V., Refusing to sing: gender, kinship and patriliny in Macedonia, 2005 (dostopno na: http://www.highbeam.com/library/docfree.asp?D OCID=1G1:131433227\&ctrlInfo=Round19\%3AMode19a\%3ADocG\% 3AResult\&ao=).

Svetieva, A., The Status of the Woman in the Traditional Village Community and Family, v: EthnoAnthropoZoom, Journal of the department of Ethnology, 2000 (dostopno na: http://www.iea.pmf.ukim.edu.mk/EAZ/ EAZ_00/Contents_EAZ_00.htm).

Todorova, M., Imaginarij Balkana, Ljubljana 2001.

Vale de Almeida, M., The hegemonic male: Masculinity in a Portuguese town, New directions in anthropology, Vol. 4., Providence in Oxford 1996.

Željazkova, A., Makedonija - edna godina sled etničeskija konflikt. Razpadane na obšestvenata təkan, v: Albanski perspektivi: Terenni proučvanija, Sofija 2003, str. 87-119. 


\section{CHAOS AND COSMOS ON THE STREETS OF GOSTIVAR}

Keywords: space, identities, interethnic relations, chaos and cosmos

\section{Abstract}

This paper focuses on the streets in Gostivar, Macedonia, and how its young Albanian and Macedonian inhabitants perceive them. I am interested in how the ethnic division in the town influences perceptions and behavior. Macedonian girls are exposed to verbal sexual advances and harassment by Albanians, whereas boys are exposed to occasional fights. On the other hand, among Albanian youth the fear of the Other is not as present as among the Macedonians. In seeking the reasons for this situation, I deal with the concepts of chaos and cosmos, social control, gossip, cultural differences, kinship, and patriarchy. The streets are one of the spaces where identification takes place, and gender and ethnic identities are related to interactions in the streets. By defining boundaries in space, people create and maintain the boundaries between "us" and "them." Identities are built in the process of interaction with others. The process of identification is connected to defining the similarities and differences in relation to "us." People place themselves in the center, in the sphere of the cosmos, which they relate to home, the known, order, safety, and cleanliness. They place the Other in the sphere of chaos because the Other represents the distant, the foreign, the unknown, disorder, danger, and uncleanness. Public opinion is important in maintaining identities and boundaries. Girls in particular must safeguard their honor, which is constantly under surveillance. Identification is maintained by avoiding the space of the Other. Individuals avoid it in order to maintain their good name in the eyes of their group. Through the constant maintenance of the identities and boundaries between "us" and "them," or between cosmos and chaos, one can trace the fear of losing one's own identity. Each side is afraid that they might become like "them." 